\title{
Castor cake as organic fertilizer to control gastrointestinal nematodes in pasture-raised sheep
}

\author{
Torta de mamona como adubo orgânico para o controle de nematoides \\ gastrintestinais em ovinos criados a pasto
}

\author{
Jéssica Sousa Maranguape'; Roberto Cláudio Fernandes Franco Pompeu²; Luiz da Silva Vieira²; \\ Henrique Antunes de Souza3; Eduardo Luiz de Oliveira4; Ana Márjory Paiva Sousa5; Clésio dos Santos Costa6; \\ Milena Alves dos Santos ${ }^{6}$; Patrício Leandro Pereira ${ }^{1}$; Hévila Oliveira Salles ${ }^{2 *}$ (1) \\ 'Universidade Estadual Vale do Acaraú - UVA, Campus da Betânia, Sobral, CE, Brasil \\ ${ }^{2}$ Empresa Brasileira de Pesquisa Agropecuária - Embrapa Caprinos e Ovinos, Sobral, CE, Brasil \\ ${ }^{3}$ Empresa Brasileira de Pesquisa Agropecuária - Embrapa Meio Norte, Teresina, Pl, Brasil \\ ${ }^{4}$ Empresa Brasileira de Pesquisa Agropecuária - Embrapa Pecuária Sudeste, São Carlos, SP, Brasil \\ ${ }^{5}$ Rede Nordeste de Biotecnologia - RENORBIO, Universidade Estadual do Ceará - UECE, Campus do Itaperi, Fortaleza, CE, Brasil \\ ${ }^{6}$ Universidade Federal do Ceará - UFC, Campus do Pici, Fortaleza, CE, Brasil
}

How to cite: Maranguape JS, Pompeu RCFF, Vieira LS, Souza HA, Oliveira EL, Sousa AMP, et al. Castor cake as organic fertilizer to control gastrointestinal nematodes in pasture-raised sheep. Braz J Vet Parasito/ 2020; 29(4): e021420. https://doi.org/10.1590/ S1984-29612020103

\begin{abstract}
Gastrointestinal parasitism is one of the factors that discourages farmers from raising small ruminants in cultivated pastures. To validate a soil treatment strategy to control the free-living stages of gastrointestinal nematodes (GIN), castor cake (CC) was used as a fertilizer on a pasture where sheep grazed on guinea grass under continuous stocking. On day zero, the pasture was divided into three paddocks, contaminated by GIN and treated, respectively, with CC divided into two applications $\left(2 \mathrm{CC}_{12}\right)$, $\mathrm{CC}$ in a single application $\left(\mathrm{CC}_{1}\right)$ and organic compost in a single application (control). On day 21, eight GIN-free sheep were placed in each paddock. On day 58, significant differences $(P<0.05)$ were observed: reduction of up to $66.10 \%$ in larvae. $\mathrm{g}^{-1}$ of dry mass in pastures fertilized with CC, decrease of up to $60.72 \%$ in infection rates among the animals in the groups treated with $\mathrm{CC}$, higher average daily weight gain (over 185 g.day $^{-1}$ ) and packed cell volume (over 26\%) in the groups treated with CC, when compared to the control (128 g.day $\left.{ }^{-1} ; 20.9 \%\right)$. In view of the results, the use of $\mathrm{CC}$, mainly $\mathrm{CC}_{1}$, as a fertilizer for guinea grass pastures, under continuous stocking, proved to be promising, with $63.41 \%$ effectiveness in controlling worm infestations.
\end{abstract}

Keywords: Productive performance, Haemonchus contortus, continuous stocking, Megathyrsus maximus, small ruminants, agroindustrial waste.

\begin{abstract}
Resumo
O parasitismo gastrintestinal é um dos fatores que fragiliza a exploração de pequenos ruminantes em pastagens cultivadas. Objetivando validar a estratégia de tratamento do solo para o controle dos estágios de vida livre de nematoides gastrintestinais ( $\mathrm{NGI}$ ), a torta de mamona (TM) foi utilizada como adubo, com ovinos pastejando em capimtanzânia sob lotação contínua. No dia zero, o pasto foi dividido em três piquetes, contaminados por NGl e tratados, respectivamente, com TM parcelada em duas aplicações $\left(2 \mathrm{TM}_{1 / 2}\right)$, TM em uma única aplicação ( $\mathrm{TM}_{1}$ ) e composto orgânico em única aplicação (testemunha). No dia 21, cada piquete recebeu oito ovinos livres de NGI. No dia 58, observaramse diferenças significativas $(P<0,05)$ : redução de até $66,10 \%$ de larvas. $g^{-1}$ de massa seca nas pastagens adubadas com TM; redução de até $60,72 \%$ da infecção dos animais nos grupos tratados com TM; ganho de peso médio diário (acima de $185 \mathrm{~g}$ dia-1 $^{-1}$ ) e volume globular (acima de 26\%) superior nos grupos tratados com TM, quando comparados à testemunha (128 g.dia-1; 20,9\%). Diante dos resultados, o uso da TM, principalmente TM, como adubo em pasto de capim-tanzânia, sob lotação contínua, mostrou-se promissor, com eficácia de 63,41\% para controlar a verminose.
\end{abstract}

Palavras-chave: Desempenho produtivo, Haemonchus contortus, lotação contínua, Megathyrsus maximus, pequenos ruminantes, resíduos agroindustriais. 


\section{Introduction}

Brazil has 18.9 million head of sheep (FAO, 2018), but this number does not fully meet the requirements of the domestic market. In 2017, this demand was supplemented through the importation of 6.5 thousand tons of sheep meat (FAO, 2017), justifying investments in the sector to increase national production. However, in order to increase production and maintain productive systems profitable, production costs must be reduced, which, in turn, means solving several management issues. As an example, sheep farmers sustain losses of up to $25 \%$ due to the high rate of worm infections in the flock (Peter \& Chandrawathani, 2005), which is a discouraging situation.

Some integrated parasite management (IPM) strategies have been adopted for flocks, such as rotational grazing (Hoste \& Torres-Acosta, 2011), multi-species grazing (Mahieu, 2013; Costa et al., 2011), deferment of pasture usage (Catto \& Bianchin, 2007), dietary protein supplementation (Miranda, 2018), sheep grazing times, and cultivation of plants that are less favorable for the development and survival of the immature stages of parasites (Guedes et al., 2018; Amaradasa et al., 2010).

Aiming to make another strategy available for IPM, and knowing that the vast majority of gastrointestinal nematodes live in the environment, Salles et al. (2018) analyzed the life cycle of gastrointestinal nematodes (GIN) and proposed a strategy for controlling the free-living stages of nematodes of small ruminants in the soil. This strategy is based on the use of a fertilizer that reduces the contamination of grasses by infective larvae $\left(L_{3}\right)$ and increases the amount of grass biomass, thereby contributing to reduce the $\mathrm{L}_{3} \cdot \mathrm{g}^{-1}$ of dry mass, favor the nutritional levels of grass, and indirectly, the animal, by increasing the supply of food in the pasture. Salles et al. (2019) evaluated several crop residues with anthelmintic effect in vitro and identified castor cake as a potential input to control the free-living stages of gastrointestinal nematodes.

Castor cake is a by-product of the industry left over after hot pressing castor seeds. This material can be used as an organic fertilizer or as a protein source to reduce production costs in intensive and semi-intensive farming systems, since the by-products generated by the industry must be disposed of in order to protect the environment (Aslani et al., 2007).

In view of the above, the aim here was to perform a field validation of soil treatment strategy to control the free-living stages of GIN with sheep grazing on guinea grass, under continuous stocking, using castor cake as a fertilizer on the grazing land.

\section{Material and Methods}

\section{Experimental site and period}

This study was conducted from March to May 2017 at the Três Lagoas Experimental Farm owned by Embrapa Caprinos e Ovinos, located in the municipality of Sobral, state of Ceará, Brazil. A trial was carried out with Santa Inês and Somalis sheep put out to graze on guinea grass pastures (Megathyrsus maximus cv Tanzania), established in 2009, each pasture covering an area of 0.1 hectare, which had been left undisturbed and not been used for grazing since 2015. The soil of the experimental area is classified as abrupt Orthic Chromic Luvisol.

All the procedures involving animals were performed following the regulations of the Ethics Committee on Animal Use of Embrapa Caprinos e Ovinos, under Protocol no. 03/2015.

At the beginning of the experimental period, the pasture grass was mown down to a uniform height of 20 centimeters and the soil was treated with mineral fertilizer, as described by Cantarutti et al. (1999), based on an analysis of the soil and considering systems for intermediate technological level (Table 1). Mineral fertilization was done by hand on the 0.1 ha pastures using nutrients such as single superphosphate $\left(60 \mathrm{~kg} \cdot \mathrm{ha}^{-1}\right)$, potassium chloride $\left(20 \mathrm{~kg} \mathrm{ha}^{-1}\right)$, micronutrients (20 kg.ha-1 of FTE BR-12) and urea (30 kg.ha-1).

Table 1. Chemical attributes of the soil in the experimental area.

\begin{tabular}{|c|c|c|c|c|c|c|c|c|c|c|c|c|c|c|c|}
\hline \multirow{2}{*}{ Depth(cm) } & $\mathrm{pH}$ & $O M^{*}$ & $\mathbf{P}$ & $\mathbf{K}$ & $\mathrm{SO}_{4}$ & $\mathrm{Na}$ & $\mathrm{Cu}$ & $\mathrm{Fe}$ & $\mathrm{Zn}$ & $M n$ & B & $\mathrm{Ca}$ & Mg & $\mathrm{H}+\mathrm{Al}$ & Al \\
\hline & $\left(\mathrm{H}_{2} \mathrm{O}\right)$ & g.dm ${ }^{-3}$ & \multicolumn{9}{|c|}{ 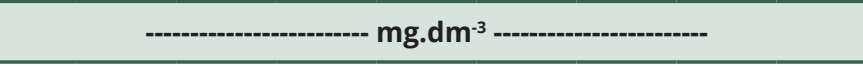 } & \multicolumn{4}{|c|}{--- $\mathrm{mmol}_{\mathrm{c}} \cdot \mathrm{dm}^{-3}$} \\
\hline $0-20$ & 6.7 & 16 & 25 & 39 & 8 & 74 & 1.1 & 28 & 2.80 & 26.2 & 0.30 & 43 & 27 & 16 & 0 \\
\hline $20-40$ & 6.8 & 9 & 18 & 39 & 6 & 128 & 1.5 & 32 & 1.90 & 23.0 & 0.12 & 46 & 30 & 16 & 0 \\
\hline
\end{tabular}

*OM: Organic Matter. 
Data on average temperature, average relative humidity, precipitation, and radiation were collected in the experimental period of March to May 2017, during the rainy season, as illustrated in Figure 1.

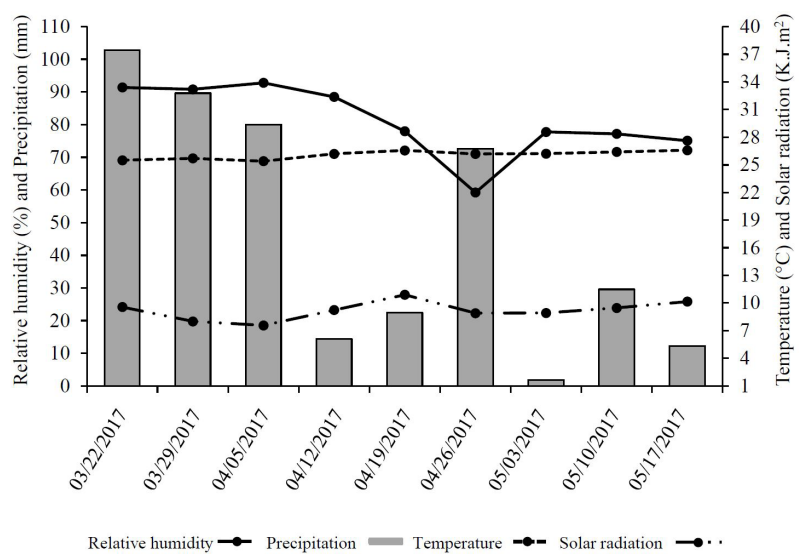

Figure 1. Relative humidity, precipitation, temperature, and solar radiation during the experimental period.

\section{Experimental design and treatments}

The experiment was carried out using a completely randomized design with repeated measures over time, with the plots representing treatments, the subplots representing collection times, and the repetitions represented by eight sheep. The inputs used were castor cake (CC), which was applied only once $\left(\mathrm{CC}_{1}\right)$ in the pasture $(195.3 \mathrm{~kg})$ at the beginning of the experiment, after the application of mineral fertilizers; $\mathrm{CC}$ applied in a fractionated way $\left(2 \mathrm{CC}_{1 / 2}\right)$, $50 \%$ after the application of mineral fertilizers $(97.7 \mathrm{~kg}$ ) and $50 \%$ thirty days after the first application (97.7 kg); and organic compost (control) applied only once $(492.6 \mathrm{~kg}$ ) after the application of the mineral fertilizers (Figure 2). The same dose of nitrogen was used in all the treatments, corresponding to the equivalent of $600 \mathrm{~kg} \cdot \mathrm{ha}^{-1}$.year ${ }^{-1}$. The CC and the organic compost contained $5.12 \%$ and 2.03\% nitrogen, respectively. All the inputs were applied by hand before allowing the animals access to the pasture, considering the use of intensive grazing under continuous stocking, with a fixed stocking rate. The organic compost was considered a control because it has no anthelmintic effect in vitro, according to the methodology used by Salles et al. (2019). The compost was based on the carcasses of small ruminants and was prepared as described by Meneses et al. (2017). The experiment involved 24 adult male sheep, noncastrated, with an initial average weight of $23.93 \pm 3.66 \mathrm{~kg}$. The animals were divided in a balanced way, according to weight and breed, into three groups of eight animals, i.e., four Somalis and four Santa Inês sheep in each treatment.

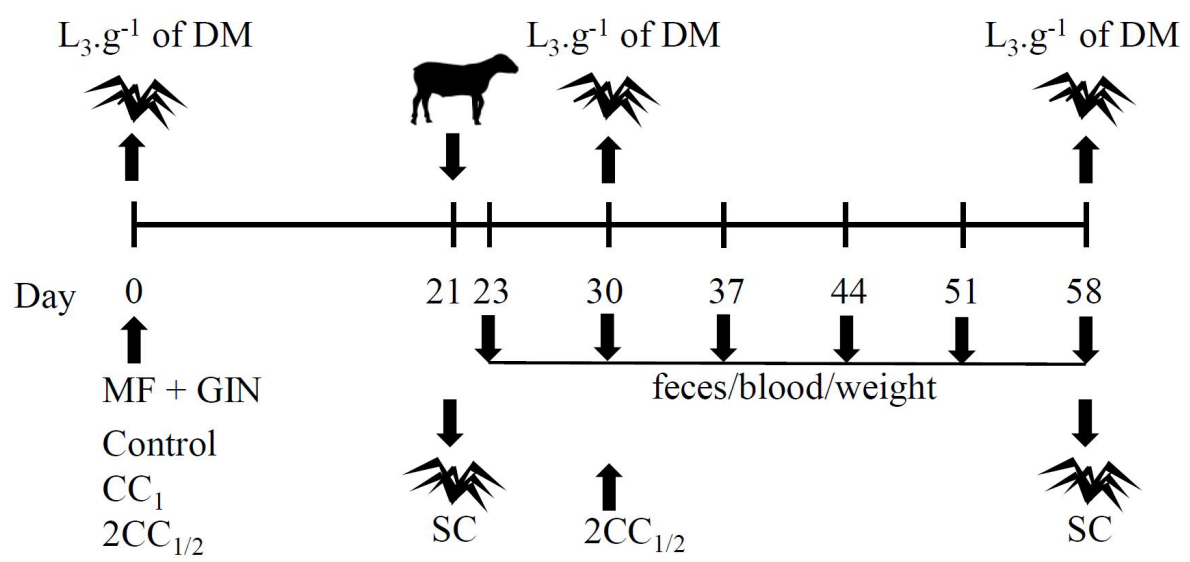

Figure 2. Timeframes and events during the experimental period (58 days). Day 0: first grass collected to determine the infective larvae count per gram of dry mass $\left(\mathrm{L}_{3} \cdot \mathrm{g}^{-1}\right.$ of $\mathrm{DM}$ ) of guinea grass, followed by mineral fertilization (MF), contamination by gastrointestinal nematodes (GIN), and treatments of the three paddocks with organic fertilizers. Control: organic compost made of small ruminant carcasses; $\mathrm{CC}_{1}$ : castor cake in a single application; $2 \mathrm{CC}_{1 / 2}$ : castor cake divided into two applications. Day 21: sheep introduced into the areas and first grass sampling to evaluate its structural characteristics (SC). Day 23: start of the weighing and collection of fecal and blood samples at seven-day intervals. Day 30: second grass sampling to determine the $\mathrm{L}_{3} \cdot \mathrm{g}^{-1}$ of DM and second application of $\mathrm{CC}_{1 / 2}$ treatment. Day 58: third grass sampling to determine the $\mathrm{L}_{3} \cdot \mathrm{g}^{-1}$ of $\mathrm{DM}$ and second grass sampling to evaluate SC. 


\section{Overall management of the experiment}

The animals received antiparasitic treatment before being driven into the paddocks, so that they were all free of infection by gastrointestinal parasites at the beginning of the experiment. This which was confirmed by counting the eggs per gram (EPG) of feces, which was equal to zero.

At the beginning of the experiment (Day 0, Figure 2), grass samples were collected from the pasture, using the methodology described by Verschave et al. (2015), with changes in the number of samples per paddock and area of collection, that is, five random samples were collected per paddock, each over an area $0.25 \mathrm{~m}^{2}$. All the grass inside this area was collected after cutting the grass close to ground level. The five samples of guinea grass from each paddock were tested by the Baermann technique (Ueno \& Gonçalves, 1998) to determine the presence of contamination by infective nematode larvae $\left(\mathrm{L}_{3}\right)$. The grass samples were then oven-dried at $60^{\circ} \mathrm{C}$, under forced ventilation for 72 hours to determine their dry mass (DM) weight. After collecting the grass samples, each paddock was contaminated with $100 \mathrm{~kg}$ of feces from infected animals (average of 2505 EPG), followed by the application of the treatments: $\mathrm{CC}_{1}$, $2 \mathrm{CC}_{1 / 2}$ and control. Twenty-one days after contamination with feces and the application of inputs on the pasture, the noninfected animals were herded into the paddocks, where the guinea grass was about $20 \mathrm{~cm}$ high. Larvae were recovered from the grass 30 and 58 days after contamination, following the method described earlier herein (Figure 2).

On the day the sheep were driven into the paddocks (Day 21, Figure 2), grass samples were collected from different parts of the paddocks to evaluate the structural characteristics (SC) of the grass. To this end, the available biomass of dry matter was determined by means of sampling points on four micro plots in each paddock. The micro plots were spaced approximately 10 meters apart by means of transects, using a $1.00 \times 0.50 \mathrm{~m}$ iron frame, and the grass inside them was cut close to the ground (Mannetje \& Jones, 2000). The samples were weighed before and after being dried in a forced air convection oven at $60^{\circ} \mathrm{C}$ for 72 hours. The green fraction was subdivided into leaves and stems to determine the total forage biomass (TFB), total leaf biomass (TLB) and leaf to stem ratio (L/S). At the end of the study (Day 58, Figure 2), another sampling was carried out to evaluate the same parameters. The following parameters were also evaluated: 1) grass canopy height, estimated by measuring the height of the grass at 15 points on each micro plot using a retractable ruler; 2) tiller population density (TPD), estimated by counting live tillers inside a $0.50 \mathrm{~m}^{2}$ frame in each micro plot; and 3) relative chlorophyll index (RCl), by measuring 15 points per micro plot using a Minolta SPAD-502 chlorophyll meter.

The animals were taken out to graze on the guinea grass pasture during the daytime and were given a concentrated supplement in the proportion of $1.8 \%$ of body weight, once a day, always at $4 \mathrm{pm}$, after being herded back into a roofed sheep barn for the night. A maximum daily consumption capacity of dry matter of $3.6 \%$ of live weight was considered for grazing sheep in the finishing phase. The centesimal composition of the concentrated supplement was as follows: Corn: 67.2, Soybean meal: 30.2, Calcitic limestone: 1.1, Dicalcium phosphate: 0.6, Ordinary salt: 1.0, and mineral Premix: at will. The concentrated supplement was formulated based on the nutrient requirements established by the National Research Council (NRC, 2007) for lambs in the finishing phase at $24 \mathrm{~kg}$ of live weight and $180 \mathrm{~g}$ of daily weight gain. Samples of the concentrated supplement and guinea grass leaves were collected at the beginning of the experiment to quantify the chemical and bromatological value of the feed (Table 2). The analyses were performed at the Animal Nutrition Laboratory of Embrapa Caprinos e Ovinos. The levels of DM (method no. 934.01), organic matter (method no. 942.05), crude protein (method no. 954.01) and ether extract (method no. 920.39) were determined according to the Association of Official Analytical Chemists - AOAC (Helrich, 1990). For the neutral detergent fiber (NDF) analysis, the samples were treated with thermostable a-amylase without sodium sulfite, and were corrected for residual ash (Mertens, 2002). Lignin was obtained by the method described by Detmann et al. (2012), and FDA residue was treated with $72 \%$ sulfuric acid.

Table 2. Chemical and bromatological composition of guinea grass leaves and concentrated supplement (\% of DM).

\begin{tabular}{ccc}
\hline Variable & Leaves (\%) & $\begin{array}{c}\text { Concentrated supplement } \\
\text { (\%) }\end{array}$ \\
Dry matter (DM) & 95.40 & 89.87 \\
Crude protein (\% of DM) & 8.86 & 20.93 \\
Neutral detergent fiber (\% of DM) & 50.36 & 28.72 \\
Acid detergent fiber (\% of DM) & 40.99 & 6.49 \\
Lignin (\% of DM) & 2.91 & 1.13 \\
Ethereal extract (\% of DM) & 1.26 & 6.74 \\
\hline
\end{tabular}




\section{Parameters of parasitological, hematological, and productive performance}

During the experimental period, at seven-day intervals, the animals were weighed, and blood and feces samples were collected (Figure 2). The EPG count in the feces was determined using the McMaster technique (Hansen \& Perry, 1994) and fecal cultures were prepared to identify the genus of the infective larvae, as proposed by Ueno \& Gonçalves (1998). The packed cell volume (PCV) in the blood samples was determined by means of a microhematocrit test (Jain, 1993). Total weight gain (TWG), average daily weight gain (ADG), and the number of days for the animal to gain $5 \mathrm{~kg}$ (D5) were evaluated. The number of days required for the animals to gain $5 \mathrm{~kg}$ (D5) was estimated by dividing this quantity in grams by the ADG.

\section{Statistical analysis}

The interaction between pasture management vs. collection days was examined when it proved significant at 5\% probability by the $\mathrm{F}$ test. The types of management were compared by the Duncan test at $5 \%$ probability. For the variables of EPG and PCV, the data were transformed into log $(x+10)$ in order to stabilize the variance. The MIXED procedure of the SAS computer program (SAS, 2002) was used as a tool for statistical analysis.

\section{RESULTS}

As can be seen in Figure 1, the experiment took place under favorable conditions for larval development in terms of relative humidity, precipitation, temperature, and solar radiation.

With regard to the recovery of infective larvae in the pasture, at the beginning of the experiment (Day 0 ) the absence of nematode larvae in the pasture was confirmed $\left(0.0 \mathrm{~L}_{3} \cdot \mathrm{g}^{-1}\right.$ of forage DM). Thirty days after the application of the treatments, this variable showed no difference $(P>0.05)$ between the types of pasture management. In fact, the effect of the inputs applied to the soil was only visible after 58 days, with a lower count of infective larvae $(P<0.05)$ in pastures fertilized with castor cake (Figure 3), corresponding to a reduction of up to $66.10 \%$ in larvae..$^{-1}$ of DM in pastures fertilized with CC.

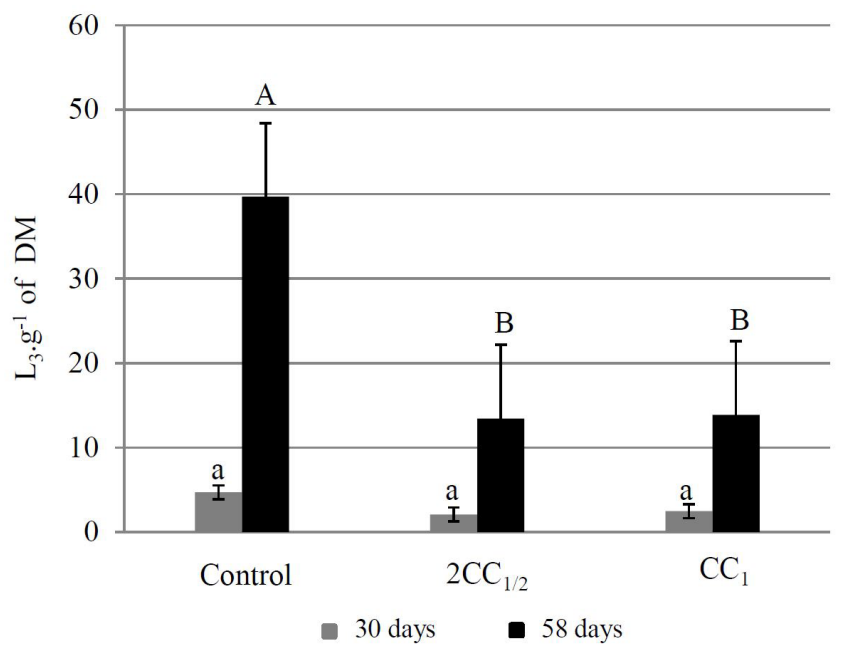

Figure 3. Infective larvae count per gram of dry mass $\left(\mathrm{L}_{3} \cdot \mathrm{g}^{-1}\right.$ of $\left.\mathrm{DM}\right)$ of guinea grass managed under continuous stocking of sheep in the rainy season in the semi-arid region of northeastern Brazil. Lower case letters indicate no statistical difference $(P>0.05)$ between treatments at 30 days, while upper case letters indicate a significant statistical difference $(P<0.05)$ between treatments at 58 days. Control: organic compost made of small ruminant carcasses; $2 C_{1 / 2}$ : castor cake divided into two applications; CC $_{1}$ : castor cake in a single application.

An analysis of the EPG values of the different types of management over time showed no difference $(P>0.05)$ between the animals that grazed in $\mathrm{CC}_{1}$ and $2 \mathrm{CC}_{1 / 2}$ as can be seen in Figure 4. However, the EPG of these two groups was significantly lower $(P<0.05)$ than that of the control group (Figure 4). In other words, the EPG was reduced by $60.72 \%$ and $39.40 \%$, respectively, after the application of $\mathrm{CC}_{1}$ and $2 \mathrm{CC}_{1 / 2}$. The animals grazing in the areas fertilized with $\mathrm{CC}\left(\mathrm{CC}_{1}\right.$ or $\left.2 \mathrm{CC}_{1 / 2}\right)$ had higher PCV than the animals grazing in the control, and this difference was significant $(\mathrm{P}<0.05)$ in the group grazing on $\mathrm{CC}_{1}$ (Figure 4). Four animals, three in the control group and one in the $2 \mathrm{CC}_{1 / 2^{\prime}}$ had a PCV below 20 and were treated with iron and an anthelmintic. One of the animals in the control group died. 

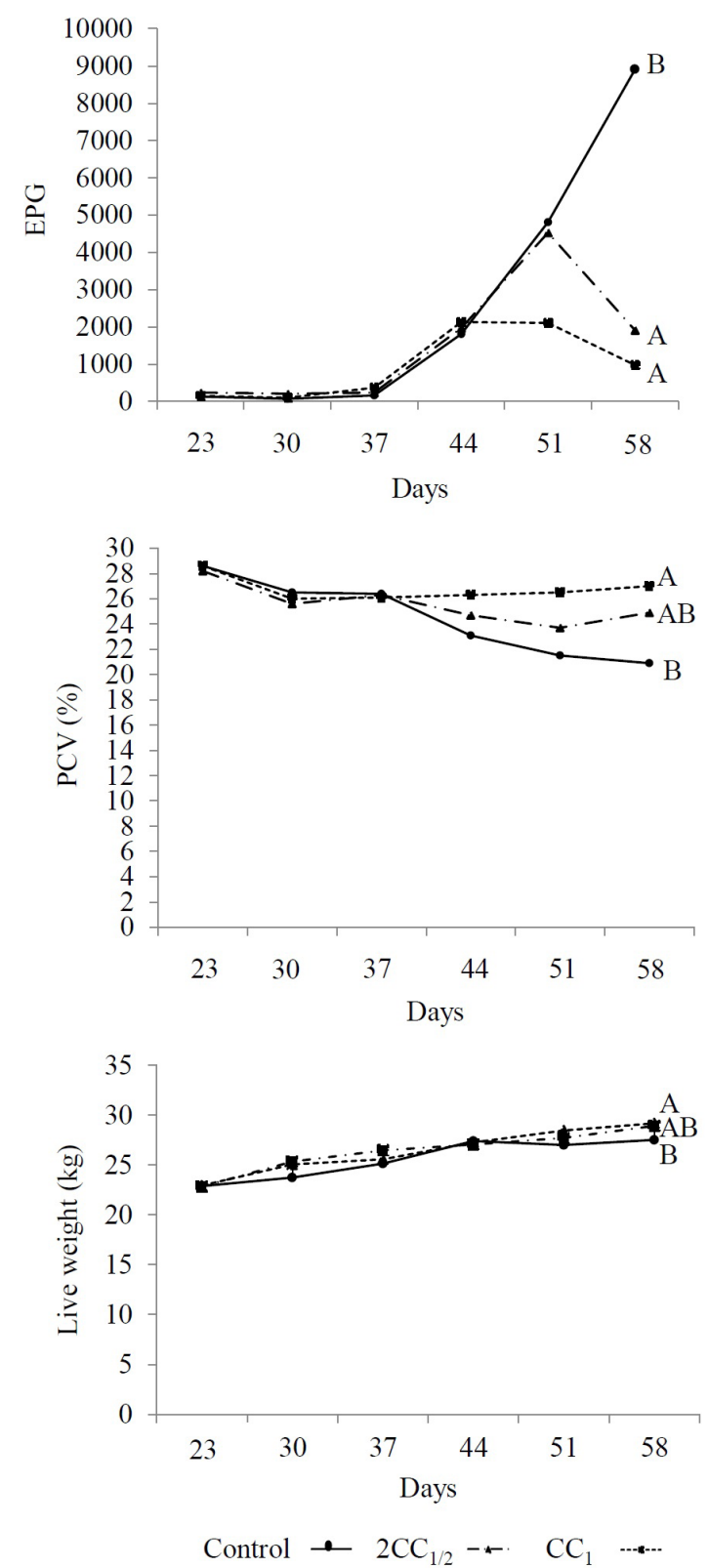

Figure 4. Eggs per gram (EPG) of feces, packed cell volume (PCV), and live weight (kg) of sheep grazing for 58 days on guinea grass fertilized with castor cake (CC) or with small ruminant carcass compost (Control). 2CC $1 / 2$ : castor cake divided into two applications; $\mathrm{CC}_{1}$ : castor cake in a single application. Different letters indicate a significant statistical difference $(P<0.05)$ between treatments.

Regardless of the treatment, the animals showed a higher prevalence of Haemonchus spp. (89.67 $\pm 3.51 \%)$ than of Oesophagostomum spp. (7.67 $\pm 3.06 \%)$ and Trichostrongylus spp. $(2.67 \pm 0.58 \%)$.

As for the structural components of the pasture evaluated on day 21 (Table 3), none of the variables under evaluation showed any difference $(P>0.05)$, which was attributed to the good uniformity of the grass before the animals were included in the experiment. However, on day 58, although the total forage biomass (TFB) of the paddocks fertilized with CC showed no difference $(P>0.05)$, these values were higher $(P<0.05)$ than in the paddock fertilized with the control. Total leaf biomass (TLB) was higher $(P<0.05)$ in the paddock fertilized with $C_{1}$, but so was stem production, resulting in a lower leaf to stem (L/S) ratio. No difference was found in the tiller population density (TPD) between paddocks fertilized with CC ( $>0.05)$. However, dividing the total amount of CC into two applications $\left(2 C_{1 / 2}\right)$ resulted in a higher GDP $(\mathrm{P}<0.05)$ than that of the control. The relative chlorophyll index $(\mathrm{RCl})$ was higher $(\mathrm{P}<0.05)$ in the paddock fertilized with $\mathrm{CC}_{1}$, where the grass was of higher quality than in the other paddocks.

As can be seen in Table 4 and Figure 4, the sheep grazing on the paddock fertilized with $\mathrm{CC}_{1}$ showed significantly higher final live weight $(P<0.05)$ than the control group, and the TWG $(P<0.05)$ for the $2 C_{1 / 2}$ was significantly higher 
Table 3. Structural components of guinea grass pasture on day 21 and 58 of the experiment.

\begin{tabular}{|c|c|c|c|}
\hline \multirow{2}{*}{ Variable } & \multicolumn{3}{|c|}{ Treatments } \\
\hline & Control* & $2 \mathrm{CC}_{1 / 2}$ & $\mathrm{CC}_{1}$ \\
\hline \multicolumn{4}{|c|}{ Day 21} \\
\hline Total forage biomass (kg DM.ha-1) & 2143.60 & 2225.40 & 2218.60 \\
\hline Total leaf biomass (kg DM.ha-1) & 1287.80 & 1293.85 & 1289.60 \\
\hline Leaf to stem ratio & 3.07 & 2.67 & 2.65 \\
\hline Height of grass (cm) & 62.90 & 61.23 & 65.93 \\
\hline Tiller population density (tiller.m²) & 240.00 & 252.00 & 248.00 \\
\hline \multicolumn{4}{|c|}{ Day 58} \\
\hline Total forage biomass (kg DM.ha-1) & $1763.00 \mathrm{~b}$ & $1915.80 \mathrm{ab}$ & $2455.90 a$ \\
\hline Total leaf biomass (kg DM.ha-1) & $574.15 b$ & $627.70 b$ & $891.05 a$ \\
\hline Leaf to stem ratio & $1.07 a b$ & $1.42 \mathrm{a}$ & $0.81 b$ \\
\hline Height of grass $(\mathrm{cm})$ & $29.39 b$ & $33.01 b$ & $37.16 a$ \\
\hline Tiller population density (tiller. $\mathrm{m}^{-2}$ ) & $238.00 b$ & $276.00 a$ & $256.00 a b$ \\
\hline Relative chlorophyll index (in SPAD units) & $27.47 b$ & $28.41 b$ & $32.16 a$ \\
\hline
\end{tabular}

${ }^{*}$ Control: organic compost made of small ruminant carcasses; $2 \mathrm{CC}_{1 / 2}$ : castor cake divided into two applications; $\mathrm{CC}_{1}$ : castor cake in a single application. DM: dry matter. Mean values followed by different letters on the same line differ statistically $(P<0.05)$ by Duncan's test.

Table 4. Productive performance of sheep after 58 days of grazing on pasture subjected to different treatments.

\begin{tabular}{|c|c|c|c|}
\hline \multirow{2}{*}{ Variable } & \multicolumn{3}{|c|}{ Treatments } \\
\hline & Control* & $2 \mathrm{CC}_{1 / 2}$ & $\mathrm{CC}_{1}$ \\
\hline Final live weight (kg) & $27.04 b$ & 29.33ab & $29.68 a$ \\
\hline Total weight gain - TWG (kg) & $3.85 b$ & $5.95 a$ & $5.58 a$ \\
\hline Average daily weight gain - ADG (g.day ${ }^{-1}$ ) & $128.33 b$ & 198.34a & $185.83 a$ \\
\hline Number of days to gain 5 kg (days) & $43.37 a$ & $27.75 b$ & $27.25 b$ \\
\hline
\end{tabular}

*Control: organic compost made of small ruminant carcasses; $2 \mathrm{CC}_{1 / 2}$ : castor cake divided into two applications; $\mathrm{CC}_{1}$ : castor cake in a single application; Mean values followed by different letters on the same line differ statistically $(P<0.05)$ by Duncan's test.

when compared to the control (Table 4). As for the ADG, it was found that sheep grazed on pastures fertilized with CC did not differ $(P>0.05)$ from each other (Table 4), but were superior $(P<0.05)$ to that of the animals grazing on the control. With respect to the variable number of days for sheep to gain $5 \mathrm{~kg}$ (Table 4), no differences $(P>0.05)$ were found between sheep grazing in the paddocks treated with $\mathrm{CC}_{1}$ or $2 \mathrm{CC}_{1 / 2}$, but this number was 15.87 days less $(P<0.05)$ than in the sheep grazing on the control.

\section{Discussion}

Epidemiological studies of gastrointestinal nematodes carried out in the semiarid regions of Northeast Brazil have shown that in the rainy season, when environmental conditions are favorable for the development of the free-living stages of GIN, pastures have high populations of infective larvae (Vieira, 2008). This study demonstrated that the use of castor cake as an organic fertilizer is effective in controlling gastrointestinal parasites in pastures and grazing animals, even in this highly challenging time of year in northeastern Brazil.

The high prevalence of Haemonchus spp. in the experiment is in agreement with the findings of Coelho et al. (2010), Costa et al. (2011), Santos et al. (2014) and Silva et al. (2017), who show that H. contortus is the main species that parasitizes sheep in Brazil's northeastern states. In addition, when the parasitic load of Haemonchus spp. 
is high, i.e., equal to or greater than $60 \%$ of the total larvae found, EPG is inversely proportional to PCV, given the hematophagous activity of this parasite (Molento et al., 2004). Sheep grazing in the paddock fertilized with CC, were found to have a higher PCV $(P<0.05)$ than those grazing in the control group, confirming the effectiveness of the strategy of using CC as a fertilizer to keep the hematological parameters stable.

The low rate of parasitic infections and good PCV levels in the animals grazing in the paddocks fertilized with CC contributed strongly to the higher TWG values of the animals grazing in the paddocks where CC was applied than those of the animals grazing in the control. Fifty-eight days after the application of CC, the grass showed the highest biomass productivity, with high TLB, the fraction preferred by grazing sheep and with the highest nutritional quality, favoring their greater weight gain. This result was attributed to the greater availability of nutrients resulting from the application of CC, favoring the growth of plants, and to the high concentration of nitrogen in the input, which favored mineralization over immobilization.

Although it is known that nutrients from organic inputs are released slowly (Kiehl, 2004), climatic conditions such as high precipitation in the experimental period, humidity and temperature may have accelerated the release of nutrients, especially of soluble $\mathrm{N}$ in soil.

The sheep grazing in the paddocks fertilized with CC showed an average daily weight gain (ADG) of 192.06 g.day ${ }^{-1}$, which was $49.7 \%$ higher than that of sheep grazing in the control. This may be a consequence of the lower helminth infection rate and greater availability of forage, which resulted in the good performance of the animals. Moreover, the use of CC to control the free-living stages of gastrointestinal nematodes of small ruminants may represent a better use of nutrients, given the high $\mathrm{RCl}$ of 30.29 SPAD units at the end of the experiment, which is closely correlated with the higher crude protein content of the grass (Guimarães et al., 2011) when compared to the 27.47 SPAD units in the paddock of the control. In this study, the ADG was higher than the nutritional requirements recommended by the NRC (2007), considering the category of early maturity of sheep growing at 175 g.day ${ }^{-1}$.

It was also found that fertilizing guinea grass with CC enabled the time to slaughter of the sheep to be reduced by 15.9 days when compared to the control treatment. Sheep enter the finishing phase with an average live weight of approximately $20 \mathrm{~kg}$, and weigh between 28.0 and $32.0 \mathrm{~kg}$ when they are sold (Pompeu et al., 2009). Therefore, the less time animals spend in the pasture until they reach the slaughter weight the higher the system's turnover, and hence, the greater the number of finished lots per year and the overall profitability of the enterprise.

All the productive performance parameters of the sheep grazing on the paddocks fertilized with $\mathrm{CC}_{1}$ showed higher values $(P<0.05)$ than those of the sheep grazing on the control. This indicates that $C C$ as fertilizer promotes an increase in forage production, accompanied by a reduction in the number of $\mathrm{L}_{3} \cdot \mathrm{g}^{-1}$ of $\mathrm{DM}$, which favors the productive performance of sheep and increases their resilience to infections by gastrointestinal nematodes. In summary, considering that there was a reduction of $66.10 \%$ in $\mathrm{L}_{3} \cdot{ }^{-1}$ of DM in pastures fertilized with CC and a decrease of $60.72 \%$ in infection rates among the animals in the groups treated with CC, the soil treatment strategy showed $63.41 \%$ effectiveness in controlling worm infestations.

It is therefore worth including this strategy in IPM in order to reduce infections among animals with minimal use of synthetic anthelmintics, resulting in environmental gains by reducing residual anthelmintics in feces and animal products. Moreover, the introduction of this strategy is opportune, since consumers today expect safe food, compelling farmers to minimize the use of agrochemicals.

\section{ACKNOWLEDGMENTS}

The authors thank the Empresa Brasileira de Pesquisa Agropecuária - EMBRAPA for its financial support (Grant No. 22.16.04.038.00.00), and Brazil's Federal Agency for the Support and Improvement of Higher Education - CAPES for granting scholarships.

\section{REFERENCES}

Amaradasa BS, Lane RA, Manage A. Vertical migration of Haemonchus contortus infective larvae on Cynodon dactylon and Paspalum notatum pastures in response to climatic conditions. Vet Parasitol 2010; 170(1-2): 78-87. http://dx.doi.org/10.1016/j. vetpar.2010.01.026. PMid:20149541.

Aslani MR, Maleki M, Mohri M, Sharifi K, Najjar-Nezhad V, Afshari E. Castor Bean (Ricinus communis) toxicosis in sheep flock. Toxicon 2007; 49(3): 400-406. http://dx.doi.org/10.1016/j.toxicon.2006.10.010. PMid:17157890. 
Cantarutti RB, Martins CE, Carvalho MM, Fonseca DM, Arruda ML, Vilela H, et al. Pastagens. In: Ribeiro AC, Guimarães PTG, Alvarez VVH, editors. Recomendação para o uso de corretivos e fertilizantes em Minas Gerais: 5a. aproximação. Viçosa, MG: Comissão de Fertilidade do Solo do Estado de Minas Gerais; 1999. p. 332-341.

Catto JB, Bianchin I. Efeito de sistema de pastejo e de espécies forrageiras na contaminação da pastagem e no parasitismo por nematoides gastrintestinais em bovinos de corte. Rev Bras Saúde Prod Anim 2007; 8(4): 343-353.

Coelho WAC, Ahid SMM, Vieira LS, Fonseca ZAAS, Silva IP. Resistência anti-helmíntica em caprinos no município de Mossoró, RN. Cienc Anim Bras 2010; 11(3): 589-599. http://dx.doi.org/10.5216/cab.v11i3.5389.

Costa VMM, Simões SVD, Riet-Correa F. Controle das parasitoses gastrintestinais em ovinos e caprinos na região semiárida do Nordeste do Brasil. Pesq Vet Bras 2011; 31(1): 65-71. http://dx.doi.org/10.1590/S0100-736X2011000100010.

Detmann E, Souza MA, Valadares SC Fo, Queiroz AC, Berchielli TT, Saliba EOS, et al. Métodos para análise de alimentos. INCT Ciência Animal. Visconde do Rio Branco: Suprema; 2012.

Food and Agriculture Organization of United Nations - FAO. FAOSTAT: FAO's corporate database [online]. Rome: FAO; 2017 [cited 2020 June 1]. Available from: http://www.fao.org/faostat/en/\#data/TP

Food and Agriculture Organization of United Nations - FAO. FAOSTAT: FAO's corporate database [online]. Rome: FAO; 2018 [cited 2020 June 1]. Available from: http://www.fao.org/faostat/en/\#data/QA

Guedes FL, Salles HO, Pompeu RCFF, Sousa AMP, Araújo AM, Ximenes LV. Uso de gramíneas no controle de nematoides gastrintestinais de pequenos ruminantes. Sobral, CE: Embrapa Caprinos e Ovinos; 2018. (Comunicado técnico, Vol. 189).

Guimarães MMC, Matsumoto SN, Figueiredo MP, Cruz PG, Araújo GS. Estimativa da composição química do capim braquiária cv. Marandú por meio de um clorofilômetro portátil. Pesq Apl Agrotec 2011; 4(2): 85-98. http://dx.doi.org/10.5777/PAeT.V4.N2.05.

Hansen J, Perry B. The epidemiology, diagnosis, and control of helminth parasites of ruminants. 4th ed. Nairobi, Kenya: International Laboratory for Research on Animal Diseases; 1994.

Helrich K. Official methods of analysis of the Association of Official Analytical Chemists. 15th ed. Gaithersburg, MD: AOAC; 1990.

Hoste $\mathrm{H}$, Torres-Acosta JFJ. Non chemical control of helminths in ruminants: adapting solutions for changing worms in a changing world. Vet Parasitol 2011; 180(1-2): 144-154. http://dx.doi.org/10.1016/j.vetpar.2011.05.035. PMid:21705144.

Jain NC. Essentials of veterinary hematology. Philadelphia: Lea \& Febiger; 1993.

Kiehl EJ. Manual de compostagem: maturação e qualidade do composto. 4th ed. Piracicaba: Editora Degaspari; 2004.

Mahieu M. Effects of stocking rates on gastrointestinal nematode infection levels in a goat/cattle rotational stocking system. Vet Parasito/ 2013; 198(1-2): 136-144. http://dx.doi.org/10.1016/j.vetpar.2013.08.029. PMid:24074701.

Mannetje L't, Jones RM. Measuring biomass of grassland vegetation. In: Mannetje L't, Jones RM, editors. Field and laboratory methods for grassland and animal production research. Wallingford: CABI Publishing; 2000. p. 151-178.

Meneses AJG, Cândido MJD, Pompeu RCFF, Souza HA, Pereira GDAC, Primo AA, et al. Structural characteristics of elephant grass fertilized with organic composted waste from production and slaughter of small ruminants. Semina: Ciênc Agrár 2017; 38(3): 1521-1536. http://dx.doi.org/10.5433/1679-0359.2017v38n3p1511.

Mertens DR. Gravimetric determination of amylase-treated neutral detergent fiber in feeds with refluxing in beakers or crucibles: collaborative study. J AOAC Int 2002; 85(6): 1217-1240. PMid:12477183.

Miranda RC. Níveis de proteína e energia dietéticos para redução do parasitismo gastrintestinal em ovinos artificialmente infectados [tese]. Tocantins: Universidade Federal do Tocantins; 2018.

Molento MB, Tasca C, Gallo A, Ferreira M, Bononi R, Stecca E. Método Famacha como parâmetro clínico individual de infecção por Haemonchus contortus em pequenos ruminantes. Cienc Rural 2004; 34(4): 1139-1145. http://dx.doi.org/10.1590/S010384782004000400027.

National Research Council - NRC. Nutrient requirements of small ruminants. New York: National Academy of Sciences; 2007.

Peter JW, Chandrawathani P. Haemonchus contortus: parasite problem No. 1 from tropics - polar circle: problems and prospects for control based on epidemiology. Trop Biomed 2005; 22(2): 131-137. PMid:16883278.

Pompeu RCFF, Cândido MJD, Neiva JNM, Rogério MCP, Cavalcante MAB, Silva RG. Desempenho de ovinos em capim-tanzânia sob lotação rotativa com quatro proporções de suplementação concentrada. Arq Bras Med Vet Zootec 2009; 61(5): $1104-1111$. http://dx.doi.org/10.1590/S0102-09352009000500013.

Salles HO, Braga ACL, Nascimento DR, Prado MSM, Souza HA, Oliveira EL, et al. Crop residues activity against the free-living stages of small ruminant nematodes. Rev Bras Parasito/ Vet 2019; 28(3): 528-532. http://dx.doi.org/10.1590/s1984-29612019024. PMid:31483029. 
Salles HO, Pompeu RCFF, Vieira LS, Cavalcante ACR, Souza HA, Guedes FL, et al. Econemat®: Estratégia de controle da fase livre de nematoides gastrintestinais de pequenos ruminantes no solo. Sobral, CE: Embrapa Caprinos e Ovinos; 2018. (Comunicado técnico; vol. 173).

Santos JM, Monteiro JP, Ribeiro WL, Macedo IT, Camurça-Vasconcelos AL, Vieira LS, et al. Identification and quantification of benzimidazole resistance polymorphisms in Haemonchus contortus isolated in Northeastern Brazil. Vet Parasitol 2014; 199(3-4): 160-164. http://dx.doi.org/10.1016/j.vetpar.2013.11.006. PMid:24295955.

SAS INSTITUTE - SAS. System for Windows. Version 9.0. Cary: SAS Institute Inc.; 2002. CD-ROM.

Silva IA, Santos ACG, Borges JO, Silva MIS. Helmintos gastrintestinais em caprinos naturalmente infectados na Ilha de São Luís, MA, Brasil. Sci Agrár Parana 2017; 16(3): 347-352. http://dx.doi.org/10.18188/1983-1471/sap.v16n3p347-352.

Ueno H, Gonçalves PC. Manual para diagnóstico das helmintoses de ruminantes. Tokyo: Japan International Cooperation Agency; 1998.

Verschave SH, Levecke B, Duchateau L, Vercruysse J, Charlier J. Measuring larval nematode contamination on cattle pastures: comparing two herbage sampling methods. Vet Parasito/ 2015; 210(3-4): 159-166. http://dx.doi.org/10.1016/j.vetpar.2015.03.031. PMid:25913455.

Vieira LS. Métodos alternativos de controle de nematóides gastrintestinais em caprinos e ovinos. Tecnol Ciênc Agropec 2008; 2(2): 49-56. 